\title{
Selective Production of Phenol on Bifunctional, Hierarchical ZSM-5 Zeolites
}

\author{
Margarita Popova 1,* Ágnes Szegedi ${ }^{2, *}$, Manuela Oykova ${ }^{1}$, Hristina Lazarova ${ }^{1}$ (D) Neli Koseva ${ }^{3}$, \\ Magdolna R. Mihályi ${ }^{2}$ and Pavletta Shestakova ${ }^{1}$
}

1 Institute of Organic Chemistry with Centre of Phytochemistry, Bulgarian Academy of Sciences, 1113 Sofia, Bulgaria; Manuela.Oykova@orgchm.bas.bg (M.O.); Hristina.Lazarova@orgchm.bas.bg (H.L.); Pavletta.Shestakova@orgchm.bas.bg (P.S.)

2 Research Centre for Natural Sciences, Institute of Materials and Environmental Chemistry, Magyar tudósok krt.2., 1117 Budapest, Hungary; mihalyi.magdolna@ttk.hu

3 Institute of Polymers, Bulgarian Academy of Sciences, 1113 Sofia, Bulgaria; koseva@polymer.bas.bg

* Correspondence: Margarita.Popova@orgchm.bas.bg (M.P.); szegedi.agnes@ttk.hu (Á.S.)

Citation: Popova, M.; Szegedi, Á.; Oykova, M.; Lazarova, H.; Koseva, N.; Mihályi, M.R.; Shestakova, P. Selective Production of Phenol on Bifunctional, Hierarchical ZSM-5 Zeolites. Molecules 2021, 26, 3576. https://doi.org/10.3390/ molecules 26123576

Academic Editor: Serena Esposito

Received: 13 May 2021

Accepted: 8 June 2021

Published: 11 June 2021

Publisher's Note: MDPI stays neutral with regard to jurisdictional claims in published maps and institutional affiliations.

Copyright: () 2021 by the authors. Licensee MDPI, Basel, Switzerland. This article is an open access article distributed under the terms and conditions of the Creative Commons Attribution (CC BY) license (https:// creativecommons.org/licenses/by/ $4.0 /)$.

\begin{abstract}
Mono- and bimetallic Ni-, Ru- and Pt-modified hierarchical ZSM-5 materials were prepared by impregnation technique and characterized by X-ray diffraction (XRD), $\mathrm{N}_{2}$ physisorption, temperature-programmed reduction (TPR-TGA), ATR-FTIR and solid state NMR spectroscopy. Formation of finely dispersed nickel, ruthenium and platinum species was observed on the bimetallic catalysts. It was found that the peculiarity of the used zeolite structure and the modification procedure determine the type of formed metal oxides and their dispersion and reducibility. The samples' acidity was studied via FTIR spectroscopy of adsorbed pyridine. The changes in the zeolite structure were studied via solid-state NMR spectroscopy. The catalysts were investigated in a gas-phase hydrodeoxygenation, transalkylation and dealkylation reaction of model lignin derivative molecules for phenol production.
\end{abstract}

Keywords: hierarchical ZSM-5 zeolite; bifunctional catalysts; phenol production; gas phase reaction

\section{Introduction}

Significant development in industrial activities has caused environmental hazards, irreparable damage to ecosystems and adverse consequences for human health [1-3]. The replacement of fossil fuels with alternative energy sources could address this problem. Lignocellulosic biomass is a promising inexpensive renewable material that could satisfy society's requirements for chemicals and fuels. Lignin, cellulose and hemicellulose are the three principal components of lignocellulosic biomass. Lignin is the main component of lignocellulosic biomass (15-30 wt\%) and is still not sufficiently used in biorefineries [3-6]. The first step in its valorization is lignin depolymerisation via hydrogenolysis $[7,8]$, oxidation [9], hydrolysis [10,11], etc. The depolymerized lignin is most often a complex mixture of phenolic compounds, hampering direct use as a high-value chemical. Subsequent catalytic processes, including selective demethoxylation and dealkylation, lead to the transformation of substituted phenols into phenol. Phenol is one of the most important aromatic chemicals used in industry with 8.9 million tons produced annually [12], which are mainly used as synthetic polymer precursors, pharmaceuticals and herbicides. Among others, ethyl- and propylphenols are the main aromatics derived from the lignin depolymerization process [13]. Catalytic conversion of alkylphenols in the gas phase to phenol and alkenes was recently reported over acidic catalysts (zeolites, $\mathrm{ZrO}_{2}$ ) [14,15]. Transalkylation is considered a promising new method for producing phenol from alkylphenols [16]. When toluene is employed as the recipient of the alkyl group, alkylated benzenes are co-produced, which can then be applied as additives to gasoline or jet fuels due to their high octane number and high calorific value. Many studies have focused on the decomposition of the 
methoxy group in phenols, i.e., demethoxylation, which is widely applied for producing biofuel from lignin [3,4]. Many catalysts have been studied in hydrodeoxygenation reactions, including supported noble and transition metals ( $\mathrm{Ru}, \mathrm{Rh}, \mathrm{Pd}, \mathrm{Pt}, \mathrm{Ni}, \mathrm{Co}, \mathrm{Fe})$ on different types of acidic supports $\left(\mathrm{Al}_{2} \mathrm{O}_{3}\right.$, USY, MCM-22, BEA, ZSM-5, etc.) [17-23].

The improvement of accessibility to the acidic sites of zeolites is a promising approach and many synthesis methods have been developed. The preparation of zeolites with a hierarchical pore structure by direct synthesis and by post-synthesis treatments has been exhaustively investigated through the years by many researchers. Acidic treatment with a mixture of $\mathrm{NH}_{4} \mathrm{~F}$ and $\mathrm{HF}$ leads to simultaneous removal of $\mathrm{Si}$ and $\mathrm{Al}$, which is very important for preservation of structure and $\mathrm{Si} / \mathrm{Al}$ ratio [23-25]. Zeolites modified by this method show greater accessibility to the active acidic sites, promoting higher catalytic activity, especially in the case of bulky and branched molecules, where the diffusion restrictions limit the reaction rate.

In this study, a hierarchical ZSM-5 zeolite was developed and its monocomponent and bimetallic modifications with $\mathrm{Ni}, \mathrm{Ru}$ and $\mathrm{Pt}$ were investigated in the gas-phase hydrodemethoxylation, transalkylation and dealkylation of 2-methoxy-4-propylphenol and 4-ethylphenol.

\section{Results and Discussion}

\subsection{Physico-Chemical Properties}

Hierarchical ZSM-5 was prepared by treatment with a mixture of $\mathrm{HF}$ and $\mathrm{NH}_{4} \mathrm{~F}$. XRD patterns of parent and hierarchical ZSM-5 samples were identical (Figure 1A), and the crystalline structure of the zeolite was not damaged by treatment with $\mathrm{HF}$ and $\mathrm{NH}_{4} \mathrm{~F}$.

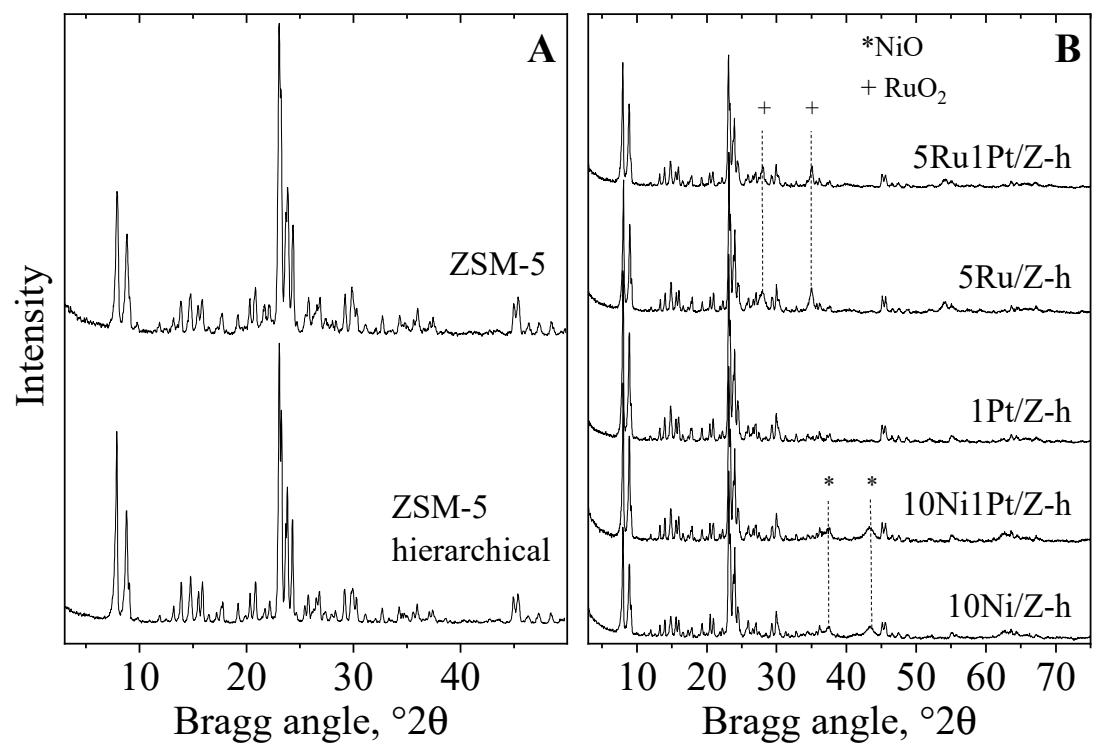

Figure 1. X-ray powder diffraction patterns of (A) initial and hierarchical ZSM-5 catalysts, and (B) the $\mathrm{Ni}-, \mathrm{Pt}-$ and Ru-modified varieties.

XRD data of the mono- and bimetallic nickel-, ruthenium- and platinum-containing zeolite materials also evidenced the preserved crystalline structure, and the presence of $\mathrm{RuO}_{2}$ and $\mathrm{NiO}$ nanoparticles [26] in the corresponding catalysts (Figure 1B). However, no traces of crystalline metallic platinum or platinum oxide compounds could be detected. It seems that Pt particles were either smaller than $5 \mathrm{~nm}$ [27] or occupied ion-exchange positions in the zeolite lattice. The crystallite size of nickel oxide particles as determined by the Scherrer equation with profile fitting method was below $10 \mathrm{~nm}$ (Table 1), whereas $\mathrm{RuO}_{2}$ nanoparticles were much bigger, $23-35 \mathrm{~nm}$. 
Table 1. Physico-chemical properties of the Z, Z-h and Ni-, Ru- and Pt-modified Z-h zeolites.

\begin{tabular}{|c|c|c|c|c|c|}
\hline Samples & $\begin{array}{l}\text { BET Surface } \\
\text { Area, }\left(\mathrm{m}^{2} / \mathrm{g}\right)\end{array}$ & $\begin{array}{c}\text { Pore } \\
\text { Volume, } \\
\left(\mathrm{cm}^{3} / \mathrm{g}\right)\end{array}$ & $\begin{array}{c}\text { Mesopore } \\
\text { Volume, } \\
\left(\mathrm{cm}^{3} / \mathrm{g}\right)\end{array}$ & $\begin{array}{l}\text { Crystallite } \\
\text { Size, }(\mathrm{nm})\end{array}$ & $\underset{\text { (\%) }}{\text { Reducibility }}{ }^{a}$ \\
\hline Z & 525 & 0.35 & 0.05 & - & - \\
\hline Z-h & 410 & 0.27 & 0.17 & - & - \\
\hline $10 \mathrm{Ni} / \mathrm{Z}-\mathrm{h}$ & 351 & 0.26 & 0.18 & $8(\mathrm{NiO})$ & $80(\mathrm{NiO})$ \\
\hline 10Ni1Pt/Z-h & 335 & 0.32 & 0.19 & $8(\mathrm{NiO})$ & $100(\mathrm{NiO})$ \\
\hline $1 \mathrm{Pt} / \mathrm{Z}-\mathrm{h}$ & 404 & 0.32 & 0.20 & - & 100 \\
\hline $5 \mathrm{Ru} / \mathrm{Z}-\mathrm{h}$ & 330 & 0.33 & 0.16 & $23\left(\mathrm{RuO}_{2}\right)$ & $60\left(\mathrm{RuO}_{2}\right)$ \\
\hline 5Ru1Pt/Z-h & 282 & 0.26 & 0.15 & $35\left(\mathrm{RuO}_{2}\right)$ & $77\left(\mathrm{RuO}_{2}\right)$ \\
\hline
\end{tabular}

a Total weight loss related to the calculated theoretical weight loss for the reduction of the corresponding oxide to its metallic state.

While Ni- and NiPt-containing samples (Table 1) showed similar metal-oxide dispersion, the ruthenium-modified ones were different. Bigger $\mathrm{RuO}_{2}$ particles were formed on the platinum-containing ruthenium catalyst by the applied synthesis method.

The metal content was determined by ICP analysis and the results confirmed that the whole amount of the impregnating metals could be found on the support (Table S1).

In Figure 2, nitrogen physisorption isotherms of the initial, hierarchical ZSM-5 zeolite and metal-containing zeolite materials are presented. The corresponding calculated parameters are listed in Table 1. The correlation coefficients of the BET curves (R) were over 0.999 in all cases (Figure S1). The preparation of Z-h led to an increase in mesopore volume (Table 1), which is evidence for the formation of a hierarchical pore structure. The impregnation procedure resulted in some decrease in specific surface area of the modified hierarchical ZSM-5 zeolite (Table 1). This means that some pores were partly blocked by the metal/metal-oxide nanoparticles. A negligible decrease in the surface area was detected for $1 \mathrm{Pt} / \mathrm{Z}$-h, whereas it was more significant for the $5 \mathrm{Ru} 1 \mathrm{Pt} / \mathrm{Z}$-h sample, probably also due to deposition of ruthenium-oxide nanoparticles in the mesopores.

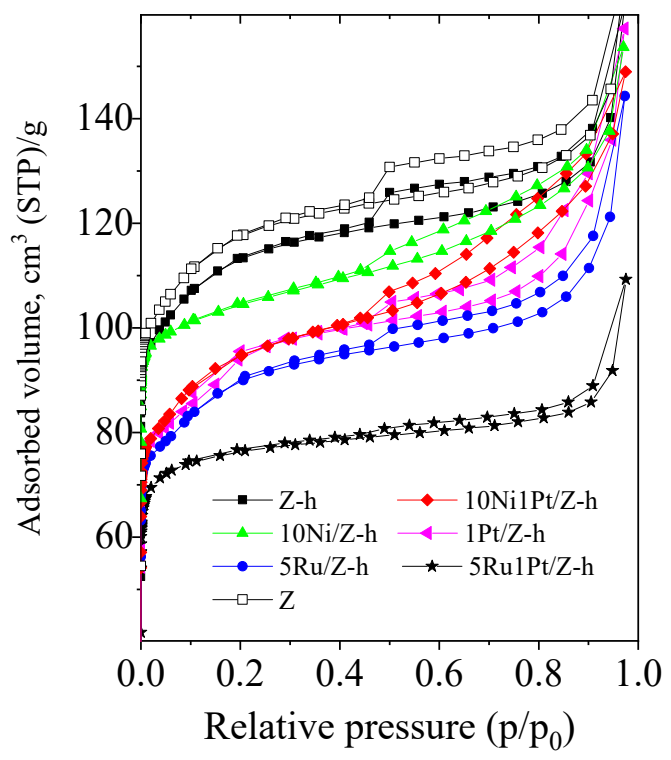

Figure 2. Nitrogen adsorption/desorption isotherms of $\mathrm{Z}$-h and the $\mathrm{Ni}$-, $\mathrm{Ru}$ - and Pt-modified Z-h zeolites.

TPR-TG profiles of the nickel, ruthenium and platinum-modified mono- and bimetallic materials are shown in Figure 3. The TPR curves of 5Ru/Z-h and 5Ru1Pt/Z-h samples showed reduction peaks of lower intensity at higher temperatures between 400 and $600{ }^{\circ} \mathrm{C}$. The TPR curves of $10 \mathrm{Ni} / \mathrm{Z}$-h and $10 \mathrm{Ni1Pt} / \mathrm{Z}-\mathrm{h}$ samples were characterized by two overlapping peaks between 200 and $450{ }^{\circ} \mathrm{C}$. The reduction step at lower temperatures can probably 
be related to the reduction in finely dispersed $\mathrm{NiO}$ particles. The higher temperature peak can be associated with the reduction in nickel ionic species incorporated into the zeolite lattice during the salt decomposition procedure by a solid-state ion-exchange procedure [28]. We infer that the presence of Ni strongly bound to the support positively influenced the platinum state and stabilized the dispersion of $\mathrm{NiO}$ particles.
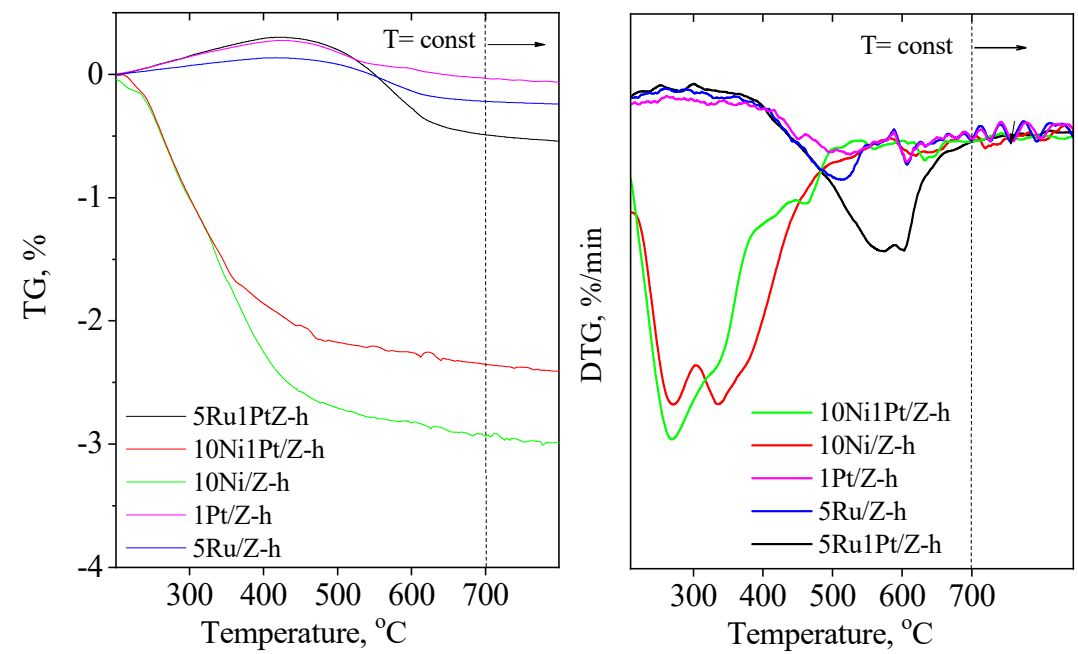

Figure 3. TG curves and TPR profiles of the Ni-, Ru- and Pt-modified hierarchical ZSM-5 zeolites.

ATR-FTIR spectra of the studied samples are presented in Figure 4. The broad and intensive peak at $1059 \mathrm{~cm}^{-1}$ for ZSM-5 and ZSM-5-h was attributed to the asymmetric stretching of $\mathrm{SiO}_{4}[29,30]$. The shift of the peak at $1059 \mathrm{~cm}^{-1}$ to higher wavenumbers was due to the incorporation of metal cations into the zeolite structure or changes in the $\mathrm{Al}$ incorporation, which was due to the different $\mathrm{Si} / \mathrm{Al}$ ratio after treatment with $\mathrm{HF}$ and $\mathrm{NH}_{4} \mathrm{~F}$ [31]. The shift was more pronounced for the 10Ni1Pt-ZSM- 5 catalyst and the peak was detected at $1072 \mathrm{~cm}^{-1}$. The stronger interaction of $\mathrm{Ni}$ and $\mathrm{Pt}$ with the support in the bimetallic catalyst was suggested by TPR experiments and could explain the observed changes in the FTIR spectrum. The shifts were smallest for 10Ni-ZSM-5-h and 5Ru-ZSM-5-h, in which the formation of crystalline metal oxides was detected.

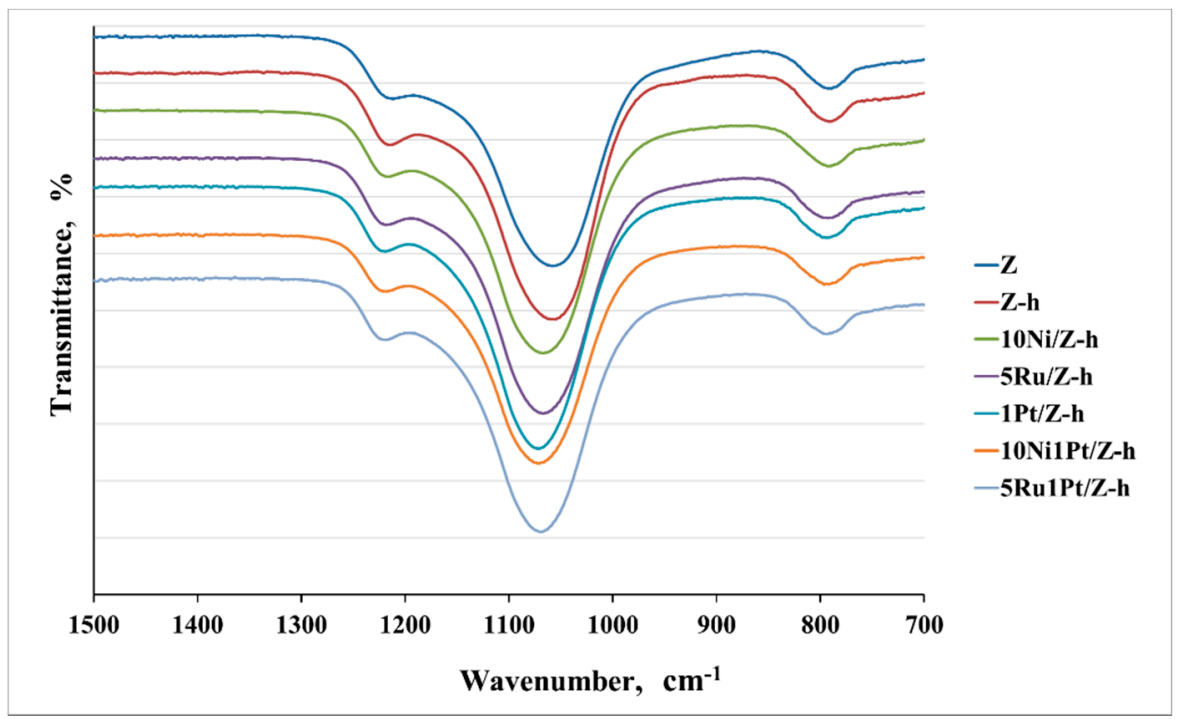

Figure 4. ATR-FTIR spectra of the studied samples.

TEM images of the 10Ni1Pt/Z-h sample show the presence of NiO and Pt nanoparticles (Figure 5A,B). Formation of bigger metal particles was registered in the 5Ru1Pt/Z-h 
catalyst due to the presence of $\mathrm{RuO}_{2}$, as shown by XRD (Figure 5C,D). The presence of $\mathrm{Pt}$ and Ni particles in 10Ni1Pt/Z-h was proven by SAED (Figure S2).

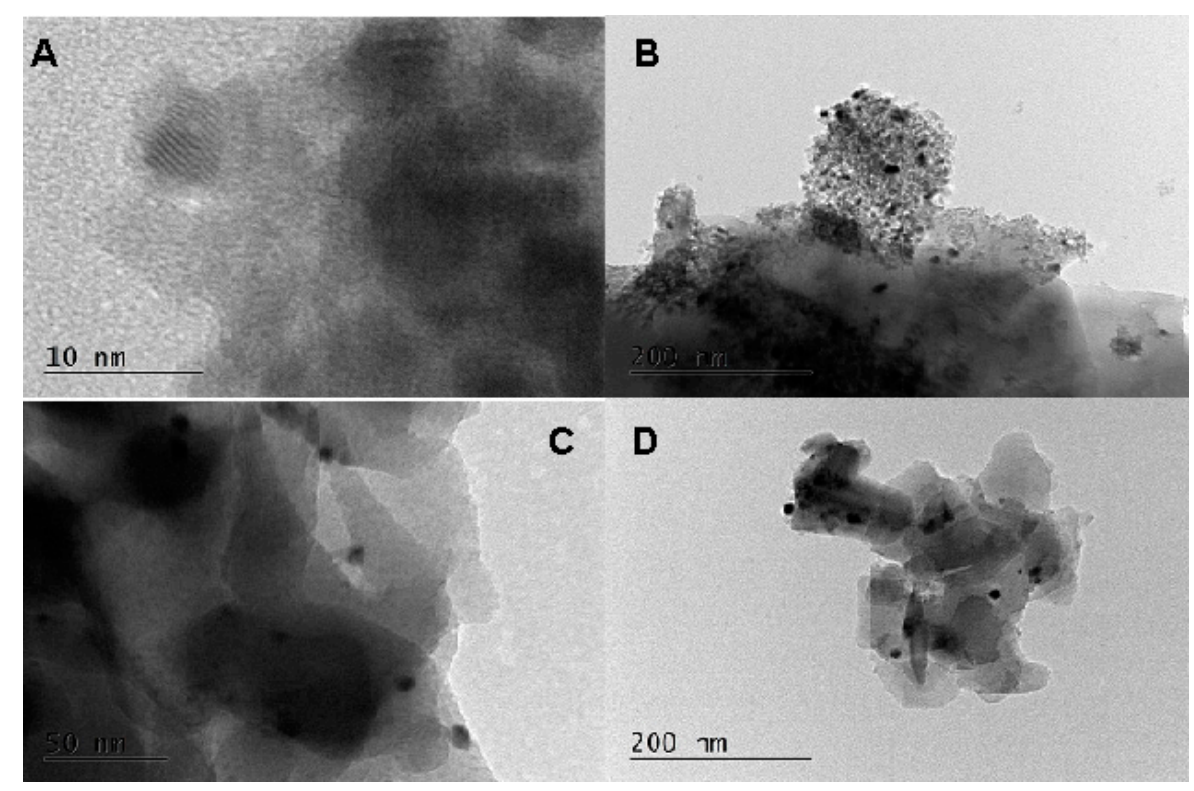

Figure 5. TEM images of 10Ni1Pt/Z-h (A,B) and 5Ru1Pt/Z-h (C,D) zeolites.

\subsubsection{FTIR Spectra of Adsorbed Pyridine}

The acidic properties of selected catalysts were characterized by FTIR spectroscopy of adsorbed pyridine (Py) in order to compare their Brønsted and Lewis acidity [32]. The FTIR spectra of the investigated samples are presented in Figure 6. The $8 \mathrm{a}, 8 \mathrm{~b}$ and $19 \mathrm{~b}$ ring vibrations $\left(v_{\mathrm{CCN}}\right)$ of Py yielded adsorption bands in the $1700-1400 \mathrm{~cm}^{-1}$ frequency region [33]. Py can be coordinated to Lewis acid sites (L-Py) or protonated on Brønsted acid centers (B-Py) of zeolites. B-Py showed a band pair at approximately $1545 / 1635 \mathrm{~cm}^{-1}$, whereas L-Py bands appeared at $1445-55$ and $1610-23 \mathrm{~cm}^{-1}$ frequencies. In zeolites Brønsted acidity stems from tetrahedrally coordinated aluminum species, where the negative charge of the framework is compensated by a proton, i.e., from bridged hydroxyl groups $\left((\equiv \mathrm{Si}-\mathrm{O})_{3} \equiv \mathrm{Al}-\right.$ $(\mathrm{OH})-\mathrm{Si} \equiv)$. Lewis acid sites are identified as Py coordinated to coordinatively unsaturated lattice cations, such as extra-framework $\mathrm{AlO}^{+}$species or other metallic/transition metallic ones. The desorption temperature of pyridine is characteristic for the strength of acidity. In zeolites Py could not be desorbed from the Brönsted and Lewis sites even at $400{ }^{\circ} \mathrm{C}$, indicating its very strong acidic character.

Both Lewis and Brønsted type acid sites could be detected on the parent ZSM- 5 zeolite (Figure 6a). The $1455 / 1623 \mathrm{~cm}^{-1}$ band pair could be associated with Py coordinatively bound to $\mathrm{AlO}^{+}$species. The Brønsted acidity of hierarchical ZSM-5 was identical with that of starting ZSM-5 (Figure 6b); the amount of Lewis acid sites was decreased, probably due to removal of extra framework cations by HF in the form of $\mathrm{AlF}_{3}$. Thus, FTIR spectroscopic results also supported that the $\mathrm{HF} / \mathrm{NH}_{4} \mathrm{~F}$ treatment did not detectably affect the framework structure of the zeolite. By impregnating the hierarchical ZSM-5 with different metals, the Brønsted acidity of the catalysts significantly decreased (Figure $6 c-e$ ). In the case of the 10Ni-Z-h sample (Figure 6c) the appearance of a new, intense band at 1451/1611 $\mathrm{cm}^{-1}$ was evidence of the incorporation of $\mathrm{Ni}^{2+}$ ions into cationic positions. It seems that during the impregnation procedure, ion exchange also occurred, and the formed nitric acid could adversely affect the acidity of the catalyst. In the $400{ }^{\circ} \mathrm{C}$ desorption spectra, Py was totally desorbed from the latter sample, indicating decreased acid strength. Other catalysts in smaller amounts still showed B-Py ring vibration even at higher temperature desorption. No incorporation of Pt or Ru ions into zeolite lattice positions could be detected by FTIR spectra. 


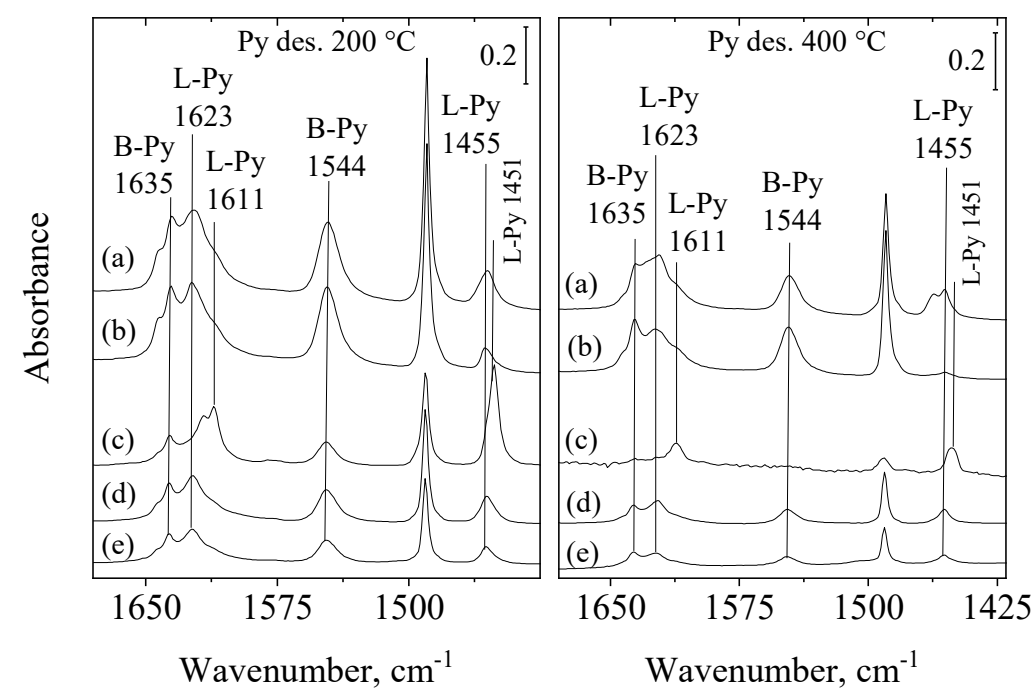

Figure 6. FTIR spectra of adsorbed pyridine on the studied catalysts: (a) parent ZSM-5, (b) hierarchical Z-h, (c) 10Ni/Z-h, (d) 1Pt/Z-h, (e) 5Ru/Z-h. Py (6 mbar) was adsorbed on $400{ }^{\circ} \mathrm{C}$ dehydrated samples at $200{ }^{\circ} \mathrm{C}$, and desorbed at 200 and $400{ }^{\circ} \mathrm{C}$ in high vacuum.

\subsubsection{NMR Analysis}

The parent, hierarchical and Ru-, Pt- and Ni-modified ZSM-5 zeolites were investigated with ${ }^{29} \mathrm{Si}$ and ${ }^{27} \mathrm{Al} \mathrm{NMR}$ spectroscopy. The ${ }^{29} \mathrm{Si} \mathrm{NMR}$ chemical shifts depend on the type and number of tetrahedrally coordinated $\mathrm{T}$ atoms $(\mathrm{T}=\mathrm{Si}, \mathrm{Al})$ in the second coordination sphere of the $\mathrm{SiO}_{4}$ unit. The five different structural environments of the tetrahedrally coordinated $\mathrm{Si}$ atoms, $\mathrm{Si}(\mathrm{OSi})_{4-\mathrm{n}}(\mathrm{OT})_{\mathrm{n}}$, designated as $\mathrm{Si}(\mathrm{nT})$, have characteristic chemical shifts in the ${ }^{29} \mathrm{Si}$ NMR spectra, while the relative intensities of the signals for the different $\mathrm{Si}(\mathrm{nT})$ species reflect the composition of the zeolite framework $(n=0,1,2,3$ and 4 represents the number of $\mathrm{Al}$ atoms sharing oxygen with the $\mathrm{SiO}_{4}$ unit). In addition to the chemical environment, the ${ }^{29} \mathrm{Si}$ chemical shifts are also sensitive to $\mathrm{Si}-\mathrm{O}$ bond lengths and $\mathrm{Si}-\mathrm{O}-\mathrm{T}$ bond angles in the crystallographically inequivalent $\mathrm{Si}$ sites. The ${ }^{29} \mathrm{Si}$ NMR spectra can be used to calculate the framework $\mathrm{Si} / \mathrm{Al}$ ratio from the NMR signal areas (I) according to Equation (1) [34]:

$$
\mathrm{Si} / \mathrm{T}=\frac{\sum_{\mathrm{n}=0}^{4} \mathrm{I}_{\mathrm{Si}(\mathrm{nT})}}{\sum_{\mathrm{n}}^{4} 0.25 \mathrm{nI} \mathrm{I}_{\mathrm{Si}(\mathrm{nT})}}
$$

The single-pulse ${ }^{29} \mathrm{Si}$ NMR spectra of the studied zeolites demonstrated three main resonances with chemical shifts at approximately $-107 \mathrm{ppm},-113 \mathrm{ppm}$ and $-115 \mathrm{ppm}$ after fitting the spectral patterns with DMFit software [35], (Figure 7).

According to data from the literature, the intense resonance at approximately $-113 \mathrm{ppm}$ and the shoulder at $-115 \mathrm{ppm}$ are assigned to two inequivalent crystallographic tetrahedral $\mathrm{Si}(0 \mathrm{Al})$ sites, while the signal at $-107 \mathrm{ppm}$ originates from $\mathrm{Si}(1 \mathrm{Al})$ species $[36,37]$. The results for the $\mathrm{Si} / \mathrm{Al}$ ratio in the studied mono- and bi-component modified ZSM5-h zeolites calculated using the areas of the fitted lines are summarized in Table 2.

The data presented in Table 2 show that the $\mathrm{Si} / \mathrm{Al}$ ratio is preserved in the monometallic $\mathrm{Ru}-$ and Ni-modified zeolites (5Ru/Z-h and $10 \mathrm{Ni} / \mathrm{Z}-\mathrm{h}$ ). Modification with Pt resulted in a higher $\mathrm{Si} / \mathrm{Al}$ ratio, indicating partial dealumination of the zeolite framework as a result of the introduction of Pt. The highest degree of dealumination was detected in the bimetallic system modified with $\mathrm{Ru}$ and Pt (5Ru1Pt/Z-h, Si / Al = 40). 

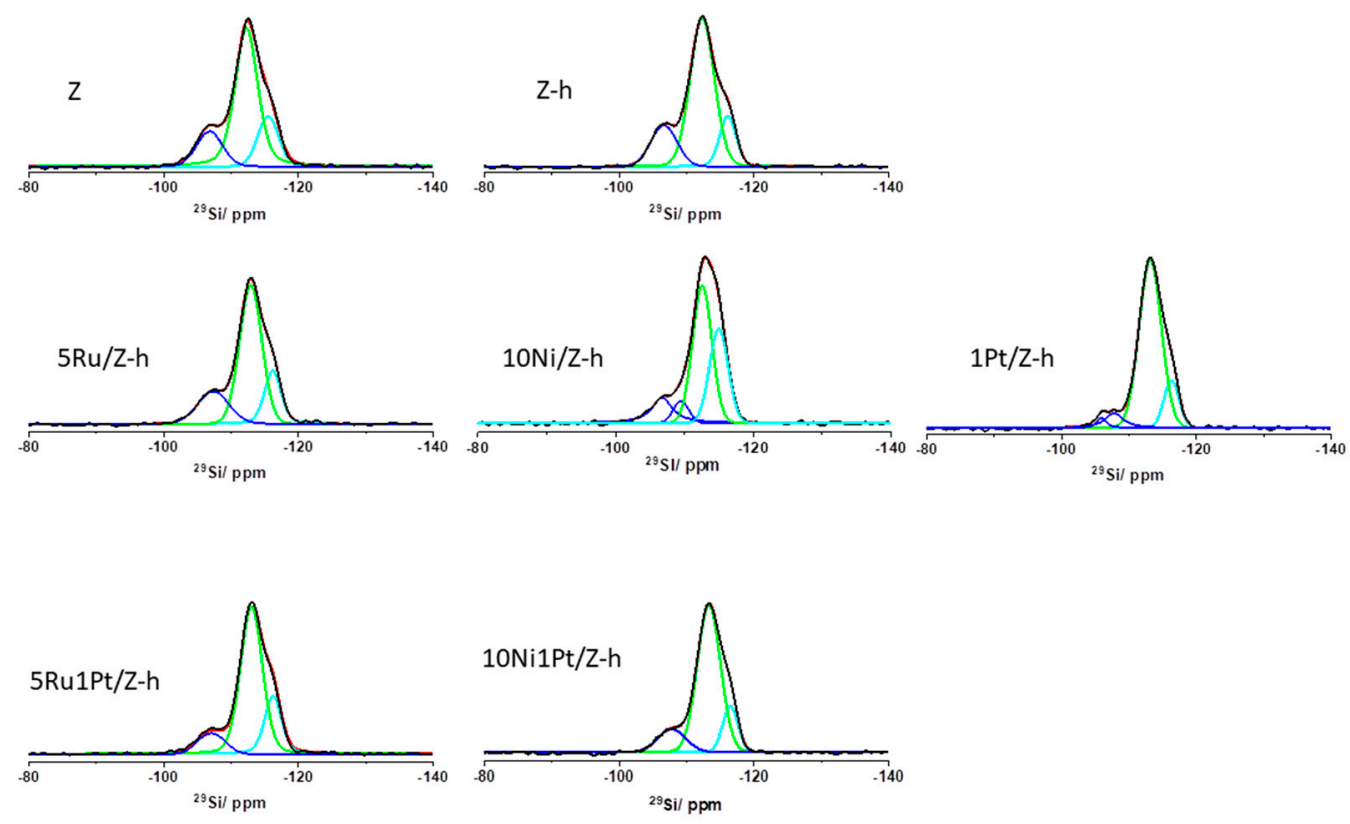

Figure 7. Experimental (black) and simulated (red) single-pulse ${ }^{29} \mathrm{Si}$ NMR spectra of the studied zeolites. The individual contributions of the different Si environments are given with colored lines (green, blue and cyan).

Table 2. Area of the signals of the different $\mathrm{Si}$ and $\mathrm{Al}$ species, obtained by deconvolution of the spectral patterns in the ${ }^{29} \mathrm{Si}$ and ${ }^{27} \mathrm{Al}$ spectra.

\begin{tabular}{|c|c|c|c|c|c|c|c|}
\hline Samples & $\begin{array}{c}Q^{4}(1 \mathrm{Al}) \\
-107 \mathrm{ppm}\end{array}$ & $\begin{array}{c}Q^{4}(0 \mathrm{Al}) \\
-113 \mathrm{ppm}\end{array}$ & $\begin{array}{c}Q^{4}(0 \mathrm{Al}) \\
-115 \mathrm{ppm}\end{array}$ & $\mathrm{Si} / \mathrm{Al}$ & $\begin{array}{c}\text { FAl } \\
62-58 \mathrm{ppm} \%\end{array}$ & $\begin{array}{l}\text { FAl distorted } \\
40-38 \text { ppm, } \%\end{array}$ & $\begin{array}{c}\text { EFAl } \\
7-0 \text { ppm \% }\end{array}$ \\
\hline$Z$ & 17 & 64 & 19 & 24 & 91 & $-/-$ & 9 \\
\hline Z-h & 19 & 65 & 16 & 21 & 72 & $-/-$ & 18 \\
\hline $5 \mathrm{Ru} / \mathrm{Z}-\mathrm{h}$ & 20 & 60 & 20 & 20 & 80 & 11 & 9 \\
\hline $10 \mathrm{Ni} / \mathrm{Z}-\mathrm{h}$ & $13+7$ & 49 & 31 & 20 & 100 & $-/-$ & $-/-$ \\
\hline $1 \mathrm{Pt} / \mathrm{Z}-\mathrm{h}$ & $3+8$ & 75 & 14 & 36 & 53 & 20 & $5+13+9$ * \\
\hline 5Ru1Pt/Z-h & 10 & 68 & 22 & 40 & 41 & 50 & $1+8$ \\
\hline 10Ni1Pt/Z-h & 14 & 71 & 15 & 29 & 32 & 62 & $4+3^{*}$ \\
\hline
\end{tabular}

* A signal at $-11 \mathrm{ppm}$, of unknown origin.

The ${ }^{27} \mathrm{Al}$ NMR spectra gave information about the coordination state of $\mathrm{Al}$ nuclei and the symmetry of their structural environment in the zeolite framework. ${ }^{27} \mathrm{Al}$ NMR spectra of the parent ZSM-5 and hierarchical Z-h zeolites (Figure 8) showed two resonances at $-60 \mathrm{ppm}$ and at approximately $0 \mathrm{ppm}$, characteristic of tetracoordinated framework $\mathrm{Al}$ sites (FAl) and of six-coordinated extra-framework Al species (EFAl), respectively. The FAl:EFAl ratio was 91:9 for the parent ZSM-5 zeolite and 71:18 for the hierarchical Z-h zeolite, indicating an increase in the amount of EFAl species as a result of the treatment. Modification with $\mathrm{Ru}, \mathrm{Ni}$ and $\mathrm{Pt}$ resulted in different degrees of structural changes as a result of the introduction of metal atoms. These structural transformations were mainly associated with distortion of the environmental symmetry of some $\mathrm{Al}$ sites, demonstrated by the appearance of a broad resonance at approximately $40-38 \mathrm{ppm}$. [38-40]. The areas of the different ${ }^{27} \mathrm{Al}$ resonances obtained by deconvolution of the ${ }^{27} \mathrm{Al}$ spectra are presented in the last three columns of Table 2. The mono- and bi-component Pt-modified zeolites also showed the presence of at least two different types of EFAl species represented by a narrow resonance at approximately $4 \mathrm{ppm}$ and a broad signal centered at approximately $7 \mathrm{ppm}$. Two of the Pt-modified zeolites, 1Pt/Z-h and 10Ni1Pt/Z-h, also showed a resonance at -11 ppm of unknown origin. The highest amount of the EFAl species was detected in the 
1Pt/Z-h sample, while in the 10Ni/Z-h zeolite, only tetracoordinated framework $\mathrm{Al}$ sites were present.
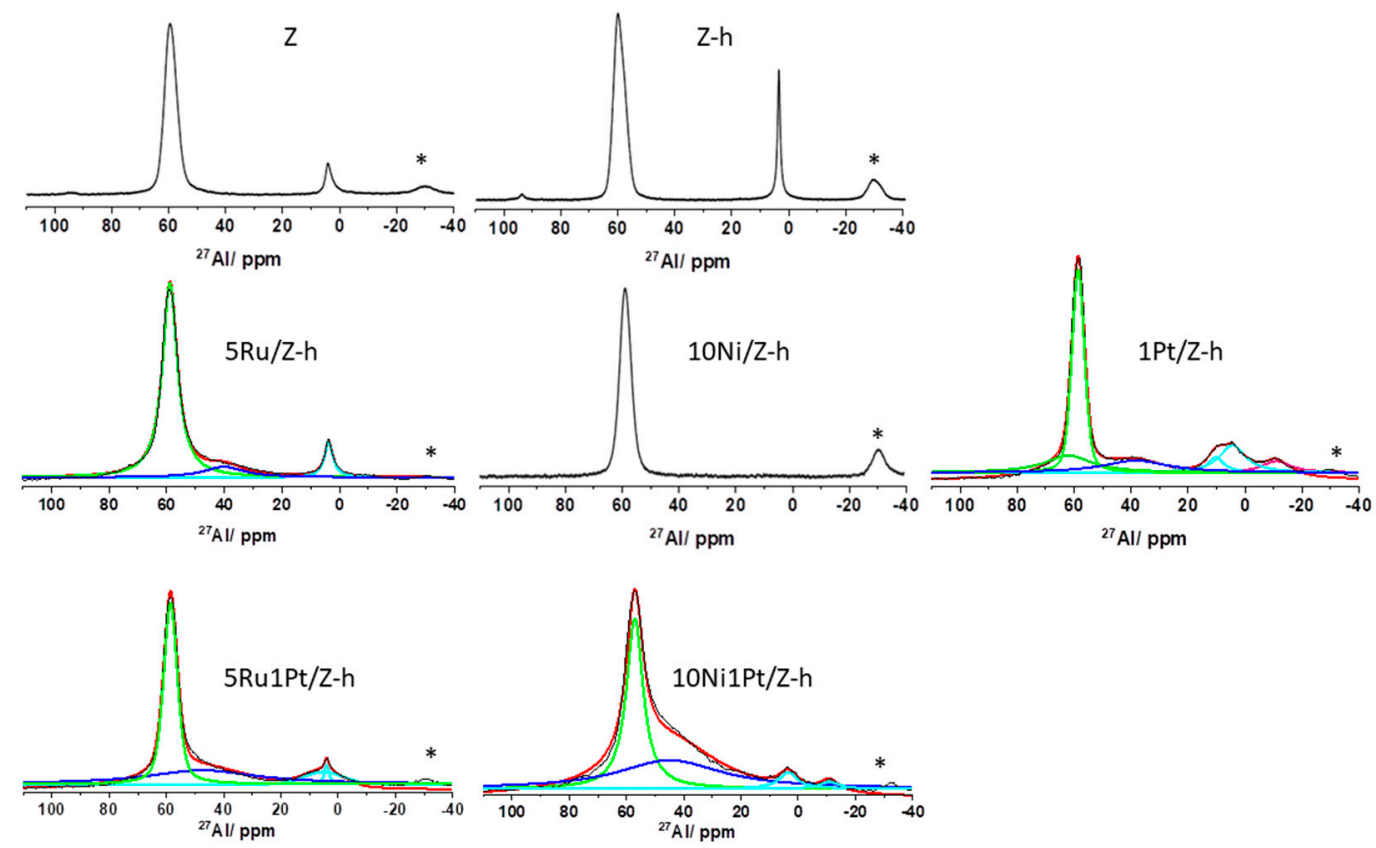

Figure 8. Experimental (black) and simulated (red) single-pulse ${ }^{27} \mathrm{Al}$ NMR spectra of the studied zeolites. The individual contributions of the different $\mathrm{Al}$ environments are given with colored lines (green, blue and cian). The FAl:EFAl ratio for ZSM-5 and ZSM-h was determined by direct integration of the two resonances. (* denotes a spinning side band).

The dealumination and structural changes in the zeolite framework are often associated with the formation of silanol groups. The chemical shift range of the $\mathrm{Si}(\mathrm{OH})$ groups is approximately $-102 \mathrm{ppm}$ and therefore the signal partially overlaps with that of the $\mathrm{Si}(1 \mathrm{Al})$ at $-107 \mathrm{ppm}$. This leads to some uncertainty in the determination of the $\mathrm{Si} / \mathrm{Al}$ ratio from the one-pulse ${ }^{29} \mathrm{Si}$ spectra, since part of the intensity of the $-102 \mathrm{ppm}$ signal, originating from the $\mathrm{SiOH}$ groups, must be attributed to the $\mathrm{Si}(0 \mathrm{Al})$ units rather than to the $\mathrm{Si}(1 \mathrm{Al})$ units. To qualitatively identify the presence of $\mathrm{SiOH}$ structural units generated at defective sites in the zeolite framework of the studied materials, ${ }^{1} \mathrm{H} \rightarrow{ }^{29} \mathrm{Si} \mathrm{CP}-\mathrm{MAS}$ spectroscopy was used. The cross polarization (CP) technique is based on transfer of polarization from abundant spins $\left({ }^{1} \mathrm{H}\right)$ to low-sensitivity nuclei $\left({ }^{29} \mathrm{Si}\right)$ via space dipole-dipolar interactions, resulting in selective enhancement of the signals from ${ }^{29} \mathrm{Si}$ sites with ${ }^{1} \mathrm{H}$ nuclei in their vicinity, originating either from $\mathrm{Si}-\mathrm{OH}$ groups or from $\mathrm{Si}(\mathrm{nAl})$ units with adjacent $\mathrm{H}$ atoms.

Figure 9 shows the overplayed ${ }^{1} \mathrm{H} \rightarrow{ }^{29} \mathrm{Si} \mathrm{CP}-\mathrm{MAS}$ spectra and the ${ }^{29} \mathrm{Si}$ single-pulse spectra of some of the studied zeolite materials. The ${ }^{1} \mathrm{H} \rightarrow{ }^{29} \mathrm{Si} \mathrm{CP}$ spectra of all materials showed a low intensity resonance at approximately $-92 \mathrm{ppm}$ characteristic of $\mathrm{Si}(2 \mathrm{OH})$ units, as well as a resonance at approximately $-102 \mathrm{ppm}$ indicating the presence of $\mathrm{Si}(1 \mathrm{OH})$ groups. There was also an enhancement of the $\mathrm{Si}(0 \mathrm{Al})$ resonances at -112 and $-115 \mathrm{ppm}$, due to possible polarization transfer from neighboring silanol protons and/or coordinated water molecules. The resonance at $-102 \mathrm{ppm}$ was partially overlapped by the signal of $\mathrm{Si}(1 \mathrm{Al})$ species at $-107 \mathrm{ppm}$; therefore the actual $\mathrm{Si} / \mathrm{Al}$ ratio might be slightly underestimated. The ${ }^{1} \mathrm{H} \rightarrow{ }^{29} \mathrm{Si} \mathrm{CP}-\mathrm{MAS}$ technique is not quantitative since the effectiveness of magnetization transfer depends on $\mathrm{Si}-\mathrm{H}$ internuclear distances and the relaxation rates and local dynamics of the structural fragments, which vary from one chemical environment to another. Considering the high number of scans necessary to achieve a reasonable signal-to-noise ratio $(\mathrm{S} / \mathrm{N})$ in the ${ }^{1} \mathrm{H} \rightarrow{ }^{29} \mathrm{Si} \mathrm{CP}$ spectra $(\mathrm{NS} \sim 20,000)$ of all materials, we can conclude that the $\mathrm{CP}$ efficiency was very low and therefore we can assume that the quantity of the silanol groups was very low. For comparison, in the quantitative single 
pulse experiment, a much higher $\mathrm{S} / \mathrm{N}$ of 110 was achieved with only 400 scans (Figure 9). The $\mathrm{S} / \mathrm{N}$ ratio detected in the ${ }^{1} \mathrm{H} \rightarrow{ }^{29} \mathrm{Si} \mathrm{CP}$ spectra of ZSM-5 and Z-h was lower by a factor of 2 as compared to the $\mathrm{S} / \mathrm{N}$ ratio in the spectra of the $\mathrm{Ru}-$, $\mathrm{Pt}$ - and Ni-modified zeolites, obtained under identical experimental conditions (NS, relaxation delay, mixing time, etc.). Therefore we can qualitatively assume that the higher CP efficiency in the metal modified zeolites is due to the presence of a larger number of silanol functions in these materials.
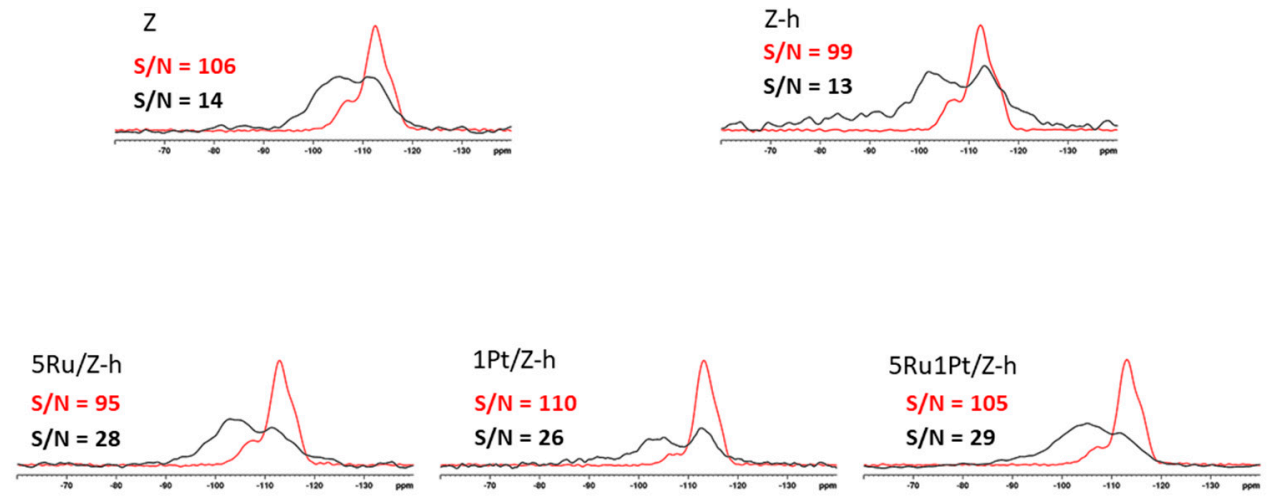

Figure 9. Comparison of the ${ }^{1} \mathrm{H} \rightarrow{ }^{29} \mathrm{Si} \mathrm{CP}$ (black) and single-pulse (red) ${ }^{29} \mathrm{Si}$ NMR spectra of the studied zeolites.

\subsection{Catalytic Activity for Phenol Preparation}

The obtained hierarchical zeolite samples (Z-h) were studied and compared with the parent ZSM-5 in dealkylation of 4-ethylphenol and transalkylation of 4-ethylphenol with toluene (Scheme 1A, Table 3). The effect of the formed mesopores led to better diffusion of reactants and products, which was more pronounced at lower temperatures in dealkylation of 4-ethylphenol. The process of transalkylation of 4-ethylphenol with toluene was more significantly affected by the presence of mesopores in Z-h than the dealkylation of 4-ethylphenol, showing much higher catalytic activity than the initial ZSM-5.

A<smiles>C=C[C+]1C=CC=[C+]C=C1C</smiles>

B<smiles>CCCc1ccc(O)c(OC)c1</smiles>

Scheme 1. 4-ethylphenol (A) and 2-methoxy-4-propylphenol (B) transformations. 
Table 3. Catalytic activity of the initial and hierarchical ZSM-5 zeolite in dealkylation of 4-ethylphenol and transalkylation of 4-ethylphenol with toluene.

\begin{tabular}{|c|c|c|c|c|c|c|}
\hline \multirow[t]{2}{*}{ Samples } & \multicolumn{3}{|c|}{$\begin{array}{l}\text { 4-Ethylphenol Dealkylation, } \\
\text { Conversion, } \%\end{array}$} & \multicolumn{3}{|c|}{ Transalkylation of 4-Ethylphenol with Toluene at $300{ }^{\circ} \mathrm{C}$} \\
\hline & $170^{\circ} \mathrm{C}$ & $200^{\circ} \mathrm{C}$ & $250{ }^{\circ} \mathrm{C}$ & Conversion, $\%$ & Selectivity to Phenol, \% & Selectivity to Xylenes, \% \\
\hline $\mathrm{Z}$ & 11.6 & 84.0 & $87.7(85.7) *$ & $\begin{array}{c}75.5 \\
(65.4) *\end{array}$ & $\begin{array}{c}54.7 \\
(53.6) *\end{array}$ & $\begin{array}{c}45.3 \\
(46.4) *\end{array}$ \\
\hline Z-h & 38.2 & 87.4 & $90.1(89.8) *$ & $\begin{array}{c}86.5 \\
(85.4) *\end{array}$ & $\begin{array}{c}35.4 \\
(34.8) *\end{array}$ & $\begin{array}{c}64.6 \\
(65.2) *\end{array}$ \\
\hline
\end{tabular}

${ }^{*}$ Results were obtained after the 3 rd reaction cycle.

Significant differences were registered in the stability of ZSM-5 and Z-h. The ZSM-5 catalyst showed a decrease in activity after three reaction cycles (Table 3) and the effect was more pronounced for transalkylation of 4-ethylphenol with toluene $(65.4 \%$ versus $75.5 \%)$. By comparison, a negligible decrease in activity of the Z-h catalyst in transalkylation of 4-ethylphenol with toluene was registered ( $85.4 \%$ versus $86.5 \%$ ).

The Ni-, Ru- and Pt-modified Z-h catalysts were studied in hydrodemethoxylation of 2-methoxy-4-propylphenol (Scheme 1B).

The conversion of 2-methoxy-4-propylphenol and the selectivity to phenol were compared at 100, 150 and $200{ }^{\circ} \mathrm{C}$ for all catalysts (Figure 10). Both conversion and phenol selectivity increased with temperature. The presence of acidic and metallic centres is important for the transformation of 2-methoxy-4-propylphenol to phenol.
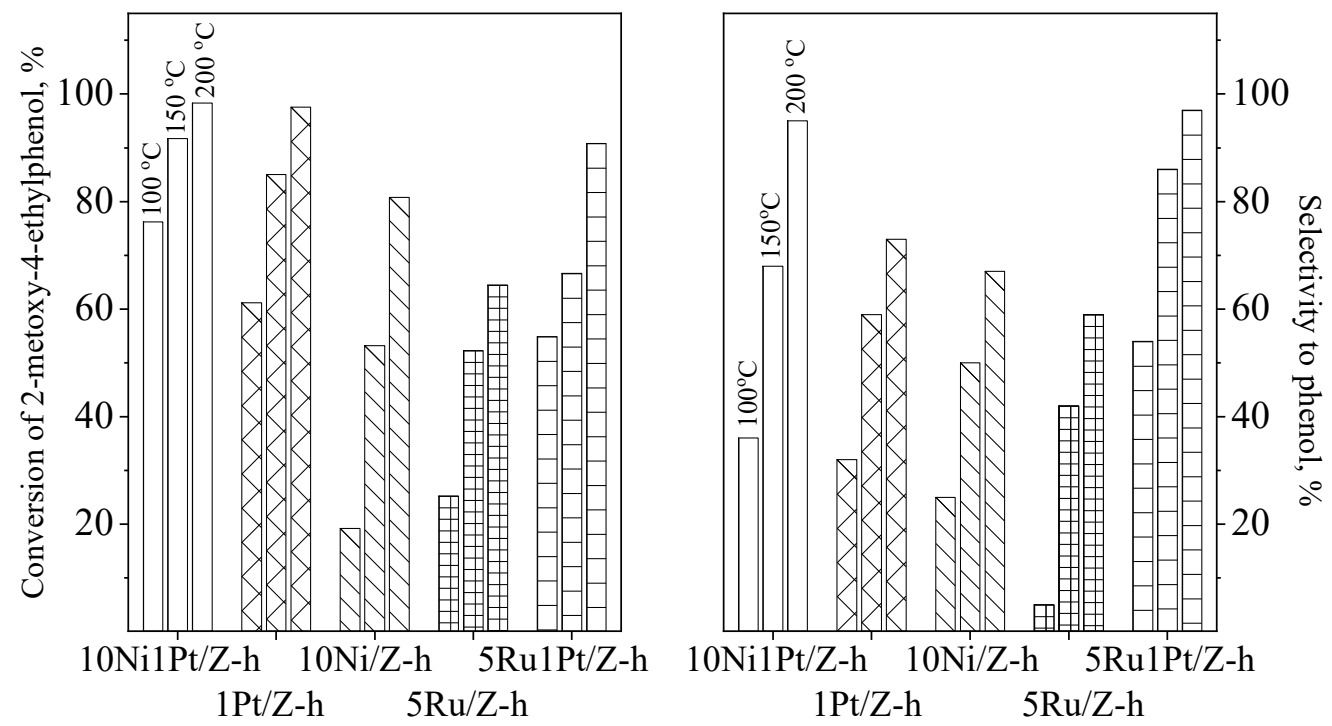

Figure 10. The catalytic activity (left) and selectivity to phenol(right) of the Ni-, Ru-, and Pt-modified hierarchical ZSM-5 zeolites in hydrodemethoxylation of 2-methoxy-4-propylphenol.

The Pt-modified ZSM-5 sample showed much higher catalytic activity than that of the $\mathrm{Ni}$ - and Ru-containing ones. The Ru-containing catalyst (5Ru/Z-h) had the lowest activity in the hydrodeoxygenation of 2-methoxy-4-propylphenol. Among the three monometallic catalysts, $1 \mathrm{Pt} / \mathrm{Z}$-h possessed the highest selectivity to phenols at all temperatures, but did not reach $80 \%$ even at $200{ }^{\circ} \mathrm{C}$. However, adding platinum to $10 \mathrm{Ni} / \mathrm{Z}$-h and $5 \mathrm{Ru} / \mathrm{Z}$-h created bimetallic catalysts (10Ni1Pt/Z-h, 5Ru1Pt/Z-5) with higher activity and significantly high selectivity to phenol. Only phenols were formed on $10 \mathrm{Ni1Pt} / \mathrm{Z}-\mathrm{h}$ and $5 \mathrm{Ru} 1 \mathrm{Pt} / \mathrm{Z}-5$ at $200{ }^{\circ} \mathrm{C}$. Both bimetallic catalysts selectively catalysed the hydrogenolysis of the $\mathrm{C}-\mathrm{O}$ bond of the methoxy group to form 4-propylphenol, which was then dealkylated to phenol on the acid sites of the catalyst. The higher hydrogenolysis activity of the $10 \mathrm{Ni1Pt} / \mathrm{Z}-\mathrm{h}$ catalyst was 
probably due to the higher degree of reduction in $\mathrm{NiO}$ in the presence of platinum, as this matches findings for other $\mathrm{Pt} / \mathrm{Ni}$ catalysts [41,42]. The simultaneous modification by nickel and platinum led to higher activity and selectivity to phenol. This effect could be explained by the stabilization of $\mathrm{Al}$ in tetrahedral position in 10Ni1Pt/Z-h as suggested by NMR in comparison to $1 \mathrm{Pt} / \mathrm{Z}-\mathrm{h}$, and by the increase in the metal dispersion and reducibility due to the additive effect of $\mathrm{Pt}$ in $10 \mathrm{Ni1} \mathrm{Pt} / \mathrm{Z}-\mathrm{h}$.

We performed XPS analysis to characterize the surface sites in 10Ni1Pt/Z-h (Figure 11). The presence of peaks for $\mathrm{Pt} 4 \mathrm{f}_{7 / 2}$ with binding energy of $72.7 \mathrm{eV}$ and $\mathrm{Pt} 4 \mathrm{f}_{5 / 2}$ binding energy of $76.1 \mathrm{eV}$ was determined in the XPS spectra, which was due to the presence of $\mathrm{Pt}^{2+}$ ions. The simultaneous presence of $\mathrm{Pt}^{0}$ and $\mathrm{Pt}^{2+}$ was found in $10 \mathrm{Ni1Pt} / \mathrm{Z}$-h as indicated by TEM and XPS data. The peak for Ni 2p, binding energy in the range of 853-855 eV due to $\mathrm{Ni}$ in nickel oxide or nickel hydroxide, was registered as well. The nickel content was predominantly exposed to the zeolite surface and could participate in the reaction as active sites, whereas only a small part of the $\mathrm{Pt}^{2+}$ was accessible to the reactant molecules after its in situ reduction before the catalytic experiment.

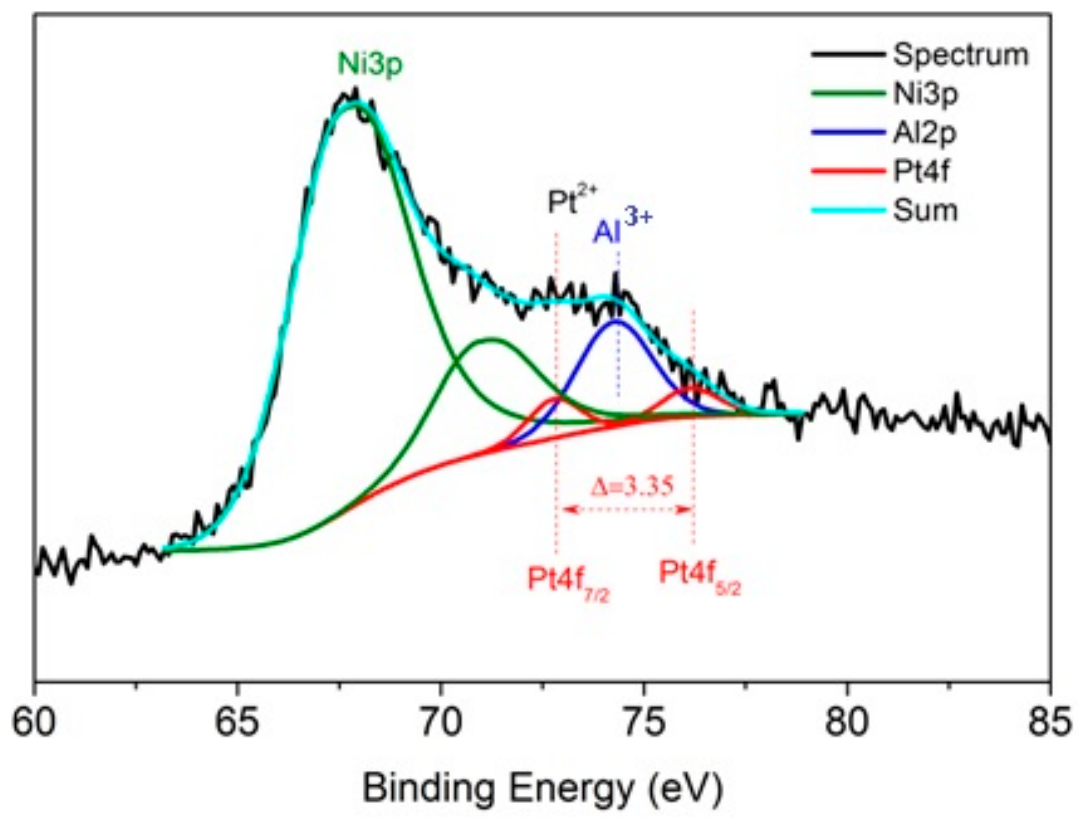

Figure 11. XPS spectra of $10 \mathrm{Ni1Pt} / \mathrm{Z}-\mathrm{h}$ zeolite.

The bimetallic $5 \mathrm{Ru} 1 \mathrm{Pt} / \mathrm{Z}$ sample showed lower catalytic activity in hydrodemethoxylation of 2-methoxy-4-propylphenol but higher selectivity to phenol in comparison to $5 \mathrm{Ru} / \mathrm{Z}-\mathrm{h}$.

\section{Experimental}

\subsection{Materials}

The reagents used for the preparation of the ZSM- 5 zeolite were sodium hydroxide $(\mathrm{NaOH}$, analytical grade, Aldrich, Darmstadt, Germany), aluminum sulphate $\left(\mathrm{Al}_{2}\left(\mathrm{SO}_{4}\right)_{3} \cdot 18 \mathrm{H}_{2} \mathrm{O}\right.$, analytical grade, Aldrich), sodium carbonate $\left(\mathrm{Na}_{2} \mathrm{CO}_{3}\right.$, analytical grade, Aldrich), tetraethyl orthosilicalite (TEOS, analytical grade, Aldrich), silicon(IV)oxide, $40 \%$ in $\mathrm{H}_{2} \mathrm{O}$ colloidal dispersion $\left(\mathrm{SiO}_{2}\right.$, analytical grade, Aldrich), tetrapropylammonium hydroxide, $40 \% w / w$ aqueous solution (TPAOH, analytical grade, Aldrich) and $\mathrm{H}_{2} \mathrm{SO}_{4}$ (Aldrich). The chemicals used in the treatment were hydrofluoric acid ( $40 \%$ aqueous solution, Aldrich) and ammonium fluoride (Aldrich). All chemicals were used as received without any purification. 


\subsection{Synthesis of ZSM-5 Zeolite}

The synthesis of ZSM- 5 was carried out by hydrothermal seed-assisted synthesis with some modifications [25]. The molar ratio of the synthesis gel corresponded to $36.3 \mathrm{Na}_{2} \mathrm{O}: 3$ $\mathrm{Al}_{2} \mathrm{O}_{3}: 100 \mathrm{SiO}_{2}: 25.2 \mathrm{H}_{2} \mathrm{SO}_{4}: 3000 \mathrm{H}_{2} \mathrm{O}$. $\mathrm{NaAlO}_{2}$ and $\mathrm{NaOH}$ were mixed and the colloidal silica was added to the solution under continuous stirring over several minutes. $1 \mathrm{wt} \%$ of the seed suspension was added to the gel mixture. The obtained gel was heated at $80^{\circ} \mathrm{C}$, after which the solution of sulphuric acid was slowly added to the gel and the mixture was stirred for $1 \mathrm{~h}$. The obtained gel was transferred to autoclaves and hydrothermally synthesized at $180^{\circ} \mathrm{C}$ for $24 \mathrm{~h}$. Subsequently, the ZSM-5 powder was filtered, washed with water and dried at $100{ }^{\circ} \mathrm{C}$ overnight.

\subsection{Preparation of Hierarchical ZSM-5}

The initial ZSM-5 was treated with a mixture of hydrofluoric acid and ammonium fluoride. This mixture was prepared by adding $0.15 \mathrm{~g} \mathrm{HF}(40 \%)$ to $60 \mathrm{~mL}$ water followed by $30 \mathrm{~g} \mathrm{NH}_{4} \mathrm{~F}$. The mixture was stirred until a clear solution was formed. At this point, $500 \mathrm{mg}$ ZSM- 5 was added to the solution of $\mathrm{HF}$ and $\mathrm{NH}_{4} \mathrm{~F}$ and stirred for $1 \mathrm{~min}$, after which the sample was separated from the mixture by centrifugation. The sample was washed three times with distilled water. The parent sample was denoted as $Z$, and its hierarchical form as Z-h.

\subsection{Modification with Ni, Ru or/and Pt Nanoparticles of Hierarchical ZSM-5 Zeolite}

An impregnation technique with nickel, ruthenium and platinum salts was applied for loading of $10 \mathrm{wt} \%, 5 \mathrm{wt} \%$ and $1 \mathrm{wt} \%$ metals, respectively. The supports were heated at $160{ }^{\circ} \mathrm{C}$ for $2 \mathrm{~h}$ before the impregnation procedure.

A monometallic Ni-modified Z-h sample was prepared by the following procedure: $330 \mathrm{mg} \mathrm{Ni}\left(\mathrm{NO}_{3}\right)_{2} \cdot 6 \mathrm{H}_{2} \mathrm{O}$ was dissolved in $10 \mathrm{~mL}$ ethanol and added to $300 \mathrm{mg} \mathrm{Z}$-h support by stirring for $10 \mathrm{~min}$. The sample was then dried at $80^{\circ} \mathrm{C}$ for $18 \mathrm{~h}$ and calcined at $450{ }^{\circ} \mathrm{C}$ for $3 \mathrm{~h}$ at a rate of $1{ }^{\circ} \mathrm{C} / \mathrm{min}$. The sample was denoted as $10 \mathrm{Ni} / \mathrm{Z}-\mathrm{h}$.

A monometallic Pt-modified Z-h sample was prepared by dissolving $40.4 \mathrm{mg} \mathrm{Pt}(\mathrm{II})$ acetyl acetonate in $40 \mathrm{~mL}$ ethanol and subsequently adding the solution to $2 \mathrm{~g}$ Z-h support by stirring at room temperature for $1 \mathrm{~h}$. The ethanol solvent was removed in a rotary vacuum evaporator at $40^{\circ} \mathrm{C}$. The sample was then dried at $70^{\circ} \mathrm{C}$ for $18 \mathrm{~h}$ and calcined at $450{ }^{\circ} \mathrm{C}$ for $3 \mathrm{~h}$ at a rate of $1{ }^{\circ} \mathrm{C} / \mathrm{min}$. The sample was denoted as $1 \mathrm{Pt} / \mathrm{Z}-\mathrm{h}$.

A monometallic Ru-modified Z-h sample was prepared by dissolving $53.4 \mathrm{mg} \mathrm{RuCl} \mathrm{H}_{3}$ in $40 \mathrm{~mL}$ water and subsequently adding the solution to $500 \mathrm{mg}$ Z-h support by stirring at room temperature for $12 \mathrm{~h}$. The solvent was removed in a rotary vacuum evaporator at $40{ }^{\circ} \mathrm{C}$. The sample was then dried at $110^{\circ} \mathrm{C}$ for $12 \mathrm{~h}$ and calcined at $450{ }^{\circ} \mathrm{C}$ for $3 \mathrm{~h}$ at a rate of $1{ }^{\circ} \mathrm{C} / \mathrm{min}$. The sample was denoted as $5 \mathrm{Ru} / \mathrm{Z}-\mathrm{h}$.

A bimetallic Pt- and Ni-modified Z-h sample was prepared by the following procedure: A solution of $334.95 \mathrm{mg} \mathrm{Ni}\left(\mathrm{NO}_{3}\right)_{2} \times 6 \mathrm{H}_{2} \mathrm{O}$ in $4 \mathrm{~mL}$ ethanol was added to $609 \mathrm{mg} 1 \mathrm{Pt} / \mathrm{Z}-\mathrm{h}$ sample and dried at $80^{\circ} \mathrm{C}$ for $18 \mathrm{~h}$. The precursor salt was decomposed in air at $450^{\circ} \mathrm{C}$ at a rate of $1{ }^{\circ} \mathrm{C} / \mathrm{min}$ for $3 \mathrm{~h}$. The sample was denoted as $10 \mathrm{Ni1Pt} / \mathrm{Z}-\mathrm{h}$.

A bimetallic Ru- and Pt-modified ZSM-5-h sample was prepared by the following procedure: A solution of $71.86 \mathrm{mg} \mathrm{RuCl}$ in $10 \mathrm{~mL}$ water was added to $609 \mathrm{mg} 1 \mathrm{Pt} / \mathrm{Z}-\mathrm{h}$ sample and dried at $80^{\circ} \mathrm{C}$ for $18 \mathrm{~h}$. The precursor salt was decomposed in air at $450{ }^{\circ} \mathrm{C}$ at a rate of $1{ }^{\circ} \mathrm{C} / \mathrm{min}$ for $3 \mathrm{~h}$. The sample was denoted as $5 \mathrm{Ru} 1 \mathrm{Pt} / \mathrm{Z}-\mathrm{h}$.

\subsection{Characterization}

X-ray patterns were recorded by a Philips PW 1810/3710 diffractometer applying monochromatized $\mathrm{CuK}_{\alpha}$ radiation $(40 \mathrm{kV}, 35 \mathrm{~mA})$. Crystallite sizes of the metal oxides were determined by the Sherrer equation using FWHM values with full profile fitting methods. For the identification of crystalline phases, the ICDD database was used [26].

The specific surface area, pore volume and size of all samples were determined from $\mathrm{N}_{2}$ physisorption isotherms collected at $-196^{\circ} \mathrm{C}$ using an AUTOSORB iQ-C-MP-AG-AG 
(Quantachrome Instruments, Anton Paar brand, Boynton Beach, FL, USA). Samples were pretreated at $350{ }^{\circ} \mathrm{C}$ in vacuum.

The temperature-programmed reduction-thermogravimetric analysis (TPR-TGA) investigations were performed with a STA449F5 Jupiter-type instrument (NETZSCH Gerätebau $\mathrm{GmbH}$, Selb, Germany) equipped with a SiC furnace and sensor holders TG/TGDSC/TG-TDA type S, temperature range of RT to $1600{ }^{\circ} \mathrm{C}$. In a typical measurement, $20 \mathrm{mg}$ of a sample was placed in a microbalance ceramic crucible and heated in a flow of $5 \mathrm{vol} \%$ $\mathrm{H}_{2}$ in $\mathrm{Ar}\left(100 \mathrm{~cm}^{3} / \mathrm{min}\right)$ to $500{ }^{\circ} \mathrm{C}$ at $5{ }^{\circ} \mathrm{C} / \mathrm{min}$ and a final hold-up of $1 \mathrm{~h}$. Prior to the TPR experiments the samples were treated in situ in an air flow $\left(10^{\circ} \mathrm{C} / \mathrm{min}\right)$ up to $500{ }^{\circ} \mathrm{C}$, followed by a hold-up of $1 \mathrm{~h}$.

The TEM images were taken on a JEOL JEM 2100 TEM (200 kV) (JEOL, Tokyo, Japan). The samples were suspended in a small amount of ethanol and a drop of the suspension was deposited onto a copper grid covered by carbon supporting film and dried at ambient temperature.

ATR-FTIR spectra were recorded by means of an IRAffinity-1 "Shimadzu" Fourier Transform Infrared (FTIR) spectrophotometer with MIRacle Attenuated Total Reflectance Attachment. The instrument was equipped with a temperature-controlled, high-sensitivity DLATGS detector and an ATR attachment with KRS-5 prism. In general, 50 scans and $4 \mathrm{~cm}^{-1}$ resolution were applied. The spectral data were processed with IR solution software.

NMR spectra were recorded on a Bruker Avance II+ 600 NMR spectrometer operating at $600.01 \mathrm{MHz}{ }^{1} \mathrm{H}$ frequency $\left(119.21 \mathrm{MHz}\right.$ for ${ }^{29} \mathrm{Si}, 156.34 \mathrm{MHz}$ for $\left.{ }^{27} \mathrm{Al}\right)$, using a $4 \mathrm{~mm}$ solid-state $\mathrm{CP} / \mathrm{MAS}$ dual ${ }^{1} \mathrm{H} / \mathrm{X}$ probehead. The samples were loaded into $4 \mathrm{~mm}$ zirconia rotors and spun at magic-angle spinning (MAS) rates of $10 \mathrm{kHz}$ for ${ }^{29} \mathrm{Si}$ spectra and $14 \mathrm{kHz}$ for ${ }^{27} \mathrm{Al}$ spectra. The quantitative ${ }^{29} \mathrm{Si}$ NMR spectra were recorded with a one-pulse sequence, $90^{\circ}$ pulse length of $4.5 \mu \mathrm{s}, 3 \mathrm{~K}$ time domain data points, spectrum width of $29 \mathrm{kHz}, 400 \mathrm{scans}$ and a relaxation delay of $120 \mathrm{~s}$. The spectra were processed with an exponential window function (line broadening factor 10) and zero-filled to $16 \mathrm{~K}$ data points. ${ }^{27} \mathrm{Al}$ spectra were recorded with a one-pulse sequence, $90^{\circ}$ pulse length of $2.8 \mu \mathrm{s}, 128 \mathrm{~K}$ time domain data points, spectrum width of $780 \mathrm{kHz}, 1024$ scans and a relaxation delay of $0.5 \mathrm{~s}$. The spectra were processed with an exponential window function (line broadening factor 10). The ${ }^{1} \mathrm{H} \rightarrow{ }^{29} \mathrm{Si}$ cross-polarization MAS (CP-MAS) spectra were acquired with the following experimental parameters: ${ }^{1} \mathrm{H}$ excitation pulse of $3.6 \mu \mathrm{s}, 2 \mathrm{~ms}$ contact time, $5 \mathrm{~s}$ relaxation delay, more than 20,000 scans, MAS rate of $10 \mathrm{kHz}$. A ${ }^{1} \mathrm{H}$ SPINAL-64 decoupling scheme was used during $\mathrm{CP}$ acquisition experiments.

FTIR experiments were performed using a Nicolet Compact 640 spectrometer via the self-supported wafer technique with pyridine (Py) $(7 \mathrm{mbar})$ as probe molecule. Selfsupported pellets $(10 \times 20 \mathrm{~mm})$ were pressed from the samples, placed into the IR cell, heated up to $400^{\circ} \mathrm{C}$ in high vacuum $\left(10^{-6} \mathrm{mbar}\right)$ at a rate of $10^{\circ} \mathrm{C} / \mathrm{min}$ and dehydrated for $1 \mathrm{~h}$. Following $30 \mathrm{~min}$ contact with Py at $200{ }^{\circ} \mathrm{C}$, the sample was evacuated at 100, 200, 300 and $400{ }^{\circ} \mathrm{C}$ for $30 \mathrm{~min}$. After each evacuation step a spectrum was recorded at the IR beam temperature with a resolution of $2 \mathrm{~cm}^{-1}$. The spectra were normalized to $5 \mathrm{mg} / \mathrm{cm}^{2}$ weight of the wafers for comparison.

The film composition and electronic structure were investigated by X-ray photoelectron spectroscopy (XPS). The measurements were carried out on an AXIS Supra electron spectrometer (Kratos Analitycal Ltd., a Shimadzu Group Company) with base vacuum in the analysis chamber of $\sim 10^{-7} \mathrm{~Pa}$. The spectra were recorded using achromatic AlK $\alpha$ radiation with photon energy of $1486.8 \mathrm{eV}$ and a charge neutralisation system. The energy scale was calibrated by normalizing the $\mathrm{C} 1 \mathrm{~s}$ line of adsorbed adventitious hydrocarbons to $284.8 \mathrm{eV}$. The binding energies (BE) were determined to an accuracy of $\pm 0.1 \mathrm{eV}$. The deconvolutions of the peaks were performed using ESCApe ${ }^{\mathrm{TM}}$ (Kratos Analytical Ltd., Manchester, UK) software.

The transition and noble metal content of the samples was determined by ICP-OES analysis. Samples were digested in order to make the components water-soluble. $50 \mathrm{mg}$ of zeolite was mixed with $10 \mathrm{~mL}$ cc. $\mathrm{HF}$ in a polymer beaker and the formed $\mathrm{SiF}_{4}$ was 
evaporated in a water bath until totally dried. The HF treatment was repeated, and the remaining metal components were dissolved in $10 \mathrm{~mL}$ aqua regia. The acidic solvents were evaporated in the water bath and the dissolution procedure was repeated. The formed clear solution was transferred to a $50 \mathrm{~mL}$ volumetric flask and analyzed with a Spectro Genesis type simultaneous axial plasma ICP-OES spectrometer. For the determination of Ni content, a MU33 type multi-element standard solution was applied (CPAChem, M8A96.K1.5N.L5). $\mathrm{Pt}$ and Ru content was determined with the help of an 8 multi-element standard solution SPECTRASCAN SS-018313.

\subsection{Catalytic Activity Measurements}

Prior to the catalytic tests, samples were pretreated for $1 \mathrm{~h}$ in hydrogen $(60 \mathrm{~mL} / \mathrm{min})$ up to $400{ }^{\circ} \mathrm{C}$. Dealkylation, transalkylation and hydrodemethoxylation of 2-methoxy-4propylphenol and 4-ethylphenol was studied at atmospheric pressure using a fixed-bed flow reactor with $30 \mathrm{~mL} / \mathrm{min}$ carrier gas (hydrogen for hydrodemethoxylation and nitrogen for dealkylation and transalkylation). In the reaction $50 \mathrm{mg}$ of the sample (particle size $0.2-0.8 \mathrm{~mm}$ ) was tested and diluted with $50 \mathrm{mg}$ glass beads of the same diameter, previously checked to be inactive. The reactor itself was a quartz tube of $15 \mathrm{~mm}$ inner diameter, with the catalyst bed at the middle. A thermocouple was positioned in the catalyst bed for accurate measurement of the catalyst temperature. All gas lines of the apparatus were heated continuously at $383 \mathrm{~K}$ in order to minimize reactant and products adsorption on the tube walls. The gas stream passed through a saturator filled with 4-ethylphenol, toluene and 2-methoxy-4-propylphenol equilibrated at $80{ }^{\circ} \mathrm{C}$. The reactant was fed into the reactor at a flow rate of $30 \mathrm{~mL} / \mathrm{min}$ and catalytic tests were carried out in the temperature range 150-300 ${ }^{\circ} \mathrm{C}$ depending on the reactants used. The reaction steady state was established after $30 \mathrm{~min}$ in each temperature. On-line analysis of the reaction products was performed using a NEXIS GC-2030 ATF with a $30 \mathrm{~m}$ HP 5MS capillary column.

\section{Conclusions}

It was found that hierarchical ZSM-5 zeolite is a suitable support for the preparation of mono- and bimetallic Ni-, Ru- and Pt-containing catalysts with high activity in transformation of 2-methoxy-4-ethylphenol and 4-ethylphenol to phenol. Formation of finely dispersed nickel, ruthenium and platinum particles was registered on the catalysts. Among the studied catalysts, $10 \mathrm{Ni1Pt} / \mathrm{Z}$-h showed the highest activity and selectivity for phenol production. The 5Ru1Pt/Z-h bimetallic catalyst showed higher selectivity but lower activity in hydrodemethoxylation of 2-methoxy-4-propylphenol. FTIR spectroscopic investigation of adsorbed pyridine evidenced that the acidity of the catalysts was preserved by hierarchization, i.e., by treatment with a $\mathrm{HF}$ and $\mathrm{NH}_{4} \mathrm{~F}$ mixture. It was also found in $\mathrm{Ni}$-containing catalysts that a portion of the nickel was incorporated into the zeolite lattice to ionic positions due to the applied impregnation method. The additive effect of $\mathrm{Pt}$ was related to the increase in the metal dispersion and enhancement of $\mathrm{NiO}$ reducibility. Bimetallic 10Ni1Pt-modified hierarchical ZSM-5 zeolite is a highly active and stable catalyst for selective production of biomass-derived phenol via gas-phase hydrodeoxygenation of 2-methoxy-4-propylphenol.

Supplementary Materials: The following are available online, Figure S1: Linear fit of $\mathrm{p} /[\mathrm{n}(\mathrm{p} 0-\mathrm{p})]$ against p/p0 plots, Figure S2: SAED of 10Ni1Pt/Z-h, Table S1: Chemical composition of the studied samples.

Author Contributions: M.P., conceptualization, supervision, writing-original draft, writingreview and editing, project administration; Á.S., investigation, writing—original draft, writingreview and editing; M.O. and H.L., investigation; M.R.M., writing-original draft; P.S. and N.K. investigation, writing - original draft. All authors have read and agreed to the published version of the manuscript.

Funding: M.P., H.L. and P.S. thank the financial support of the National Science Fund of Bulgaria, grant № KП-06-KOCT/3/2018. M.P. and M.M. thank the support of the COST Action CA17128: Estab- 
lishment of a Pan-European Network on the Sustainable Valorisation of Lignin. The authors thank the Bulgarian Hungarian Inter-Academic Exchange Agreement for support. M.O. acknowledges partial support by the Bulgarian Ministry of Education and Science under the National Research Programme "Young scientists and postdoctoral students" approved by DCM \# 577/17.08.2018. P.S. thanks the project Distributed Research Infrastructure INFRAMAT, part of the Bulgarian National Roadmap for Research Infrastructures, supported by the Bulgarian Ministry of Education and Science.

Conflicts of Interest: The authors declare no conflict of interest.

Sample Availability: Samples of the hierarchical ZSM-5 zeolites are available from the authors.

\section{References}

1. Luque, R.; Campelo, J.; Clark, J. Handbook of Biofuels Production: Processes and Technologies; Woodhead Publishing Series in Energy; Elsevier: Amsterdam, The Netherlands, 2013; Volume 15.

2. Lin, C.S.K.; Pfaltzgraff, L.A.; Herrero-Davila, L.; Mubofu, E.B.; Abderrahim, S.; Clark, J.H.; Koutinas, A.; Kopsahelis, N.; Stamatelatou, K.; Dickson, F.; et al. Food waste as a valuable resource for the production of chemicals, materials and fuels. Current situation and global perspective. Energy Environ. Sci. 2013, 6, 426-464. [CrossRef]

3. Romero, Y.; Richard, F.; Brunet, S. Hydrodeoxygenation of 2-ethylphenol as a model compound of bio-crude over sulfided Mo-based catalysts: Promoting effect and reaction mechanism. Appl. Catal. B 2010, 98, 213-223. [CrossRef]

4. Zhang, J.; Lombardo, L.; Gözaydın, G.; Dyson, P.J.; Yan, N. Single-step conversion of lignin monomers to phenol: Bridging the gap between lignin and high-value chemicals Chinese. J. Catal. 2018, 39, 1445-1452. [CrossRef]

5. Serra, J.M.; Guillon, E.; Corma, A. A rational design of alkyl-aromatics dealkylation-transalkylation catalysts using C8 and C9 alkyl-aromatics as reactants. J. Catal. 2004, 227, 459-469. [CrossRef]

6. Gamliela, D.P.; Karakalos, S.; Valla, J.A. Liquid phase hydrodeoxygenation of anisole, 4-ethylphenol and benzofuran using Ni, Ru and Pd supported on USY zeolite. Appl. Catal. A 2018, 559, 20-29. [CrossRef]

7. Shao, Y.; Xia, Q.; Dong, L.; Liu, X.; Han, X.; Parker, S.F.; Cheng, Y.; Daemen, L.L.; Ramirez-Cuesta, A.J.; Yang, S.; et al. Selective production of arenes via direct lignin upgrading over a niobium-based catalyst. Nat. Commun. 2017, 8, 16104. [CrossRef] [PubMed]

8. Shuai, L.; Amiri, M.T.; Questell-Santiago, Y.M.; Héroguel, F.; Li, Y.; Kim, H.; Meilan, R.; Chapple, C.; Ralph, J.; Luterbacher, J.S. Formaldehyde stabilization facilitates lignin monomer production during biomass depolymerisation. Science 2016, 354, 329-333. [CrossRef] [PubMed]

9. Lancefield, C.S.; Ojo, O.S.; Tran, F.; Westwood, N.J. Isolation of Functionalized Phenolic Monomers through Selective Oxidation and C-O Bond Cleavage of the $\beta-\mathrm{O}-4$ Linkages in Lignin. Angew. Chem. Int. Ed. 2015, 54, 258-262. [CrossRef] [PubMed]

10. Deuss, P.J.; Scott, M.; Tran, F.; Westwood, N.J.; de Vries, J.G.; Barta, K. Aromatic monomers by in situ conversion of reactive intermediates in the acid-catalyzed depolymerization of lignin. J. Am. Chem. Soc. 2015, 137, 7456-7467. [CrossRef] [PubMed]

11. Onwudili, J.A.; Williams, P.T. Catalytic depolymerization of alkali lignin in subcritical water: Influence of formic acid and Pd/C catalyst on the yields of liquid monomeric aromatic products. Green Chem. 2014, 16, 4740-4748. [CrossRef]

12. Jung, K.B.; Lee, J.; Ha, J.M.; Lee, H.; Suh, D.J.; Jun, C.H.; Jae, J. Effective hydrodeoxygenation of lignin-derived phenols using bimetallic RuRe catalysts: Effect of carbon supports. Catal. Today 2018, 303, 191-199. [CrossRef]

13. Renders, T.; Schutyser, W.; Van den Bosch, S.; Koelewijn, S.F.; Vangeel, T.; Courtin, C.M.; Sels, B.F. Influence of Acidic (H3PO4) and Alkaline (NaOH) Additives on the Catalytic Reductive Fractionation of Lignocellulose. ACS Catal. 2016, 6, 2055-2066. [CrossRef]

14. Liao, Y.; d'Halluin, M.; Makshina, E.; Verboekend, D.; Sels, B.F. Shape selectivity vapor-phase conversion of lignin-derived 4-ethylphenol to phenol and ethylene over acidic aluminosilicates: Impact of acid properties and pore constraint. Appl. Catal. B 2018, 234, 117-129. [CrossRef]

15. Verboekend, D.; Liao, Y.; Schutyser, W.; Sels, B.F. Alkylphenols to phenol and olefins by zeolite catalysis: A pathway to valorize raw and fossilized lignocellulose. Green Chem. 2016, 18, 297-306. [CrossRef]

16. Yoshikawa, T.; Umezawa, T.; Nakasaka, Y.; Masuda, T. Conversion of alkylphenol to phenol via transalkylation using zeolite catalysts. Catal. Today 2020, 347, 110-114. [CrossRef]

17. Ohta, H.; Feng, B.; Kobayashi, H.; Haraa, K.; Fukuoka, A. Selective hydrodeoxygenation of lignin-related 4-propylphenol into n-propylbenzene in water by $\mathrm{Pt}-\mathrm{Re} / \mathrm{ZrO}_{2}$ catalysts. Catal. Today 2014, 234, 139-144. [CrossRef]

18. Shin, E.-J.; Keane, M.A. Gas-phase hydrogenation/hydrogenolysis of phenol over supported nickel catalysts. Ind. Eng. Chem. Res. 2000, 39, 883-892. [CrossRef]

19. Sun, J.; Karim, A.M.; Zhang, H.; Kovarik, L.; Li, X.S.; Hensley, A.J.; McEwen, J.-S.; Wang, Y. Carbon-supported bimetallic Pd-Fe catalysts for vapor-phase hydrodeoxygenation of guaiacol. J. Catal. 2013, 306, 47-57. [CrossRef]

20. Jin, S.; Xiao, Z.; Li, C.; Chen, X.; Wang, L.; Xing, J.; Li, W.; Liang, C. Catalytic hydrodeoxygenation of anisole as lignin model compound over supported nickel catalysts. Catal. Today 2014, 234, 125-132. [CrossRef]

21. Echeandia, S.; Pawelec, B.; Barrio, V.L.; Arias, P.L.; Cambra, J.F.; Loricera, C.V.; Fierro, J.L.G. Enhancement of phenol hydrodeoxygenation over Pd catalysts supported on mixed $\mathrm{HY}$ zeolite and $\mathrm{Al}_{2} \mathrm{O}_{3}$. An approach to O-removal from bio-oils. Fuel 2014, 117, 1061-1073. [CrossRef] 
22. Fakin, T.; Ristic, A.; Mavrodinova, V.; Zabukovec Logar, N. Highly crystalline binder-free ZSM-5 granules preparation. Micropor. Mesopor. Mater. 2015, 213, 108-117. [CrossRef]

23. Berenguer, A.; Gutiérrez-Rubio, S.; Linares, M.; Ochoa-Hernández, C.; Moreno, I.; García-Fierro, J.L.; Coronado, J.M.; Serrano, D.P.; Pizarro, P. On the Feasibility of Using Hierarchical ZSM-5 and Beta Zeolites as Supports of Metal Phosphides for Catalytic Hydrodeoxygenation of Phenol. Energy Technol. 2019, 7, 1900214. [CrossRef]

24. Li, J.; Wang, L.; Zhang, D.; Qian, J.; Liu, L. One-step synthesis of hierarchical ZSM-5 zeolites and their catalytic performance on the conversion of methanol to aromatics. Reac. Kinet. Mech. Catal. 2020, 130, 519-530. [CrossRef]

25. Li, W.; Li, F.; Wang, H.; Liao, M.; Li, P.; Zheng, J.; Tu, C.; Li, R. Hierarchical mesoporous ZSM-5 supported nickel catalyst for the catalytic hydrodeoxygenation of anisole to cyclohexane. Mol. Catal. 2020, 480, 1106422. [CrossRef]

26. Jenkins, R.; Snyder, R.L. Introduction to X-ray Powder Diffractometry; John Wiley \& Sons Inc.: Hoboken, NJ, USA, 1996; pp. 89-91.

27. Holder, C.F.; Schaak, R.E. Tutorial on Powder X-ray Diffraction for Characterizing Nanoscale Materials. ACSNano 2019, 13, 7356-7359. [CrossRef]

28. Landau, M.V.; Tavor, D.; Regev, O.; Kaliya, M.L.; Herskowitz, M.; Valtchev, V.; Mintova, S. Colloidal nanocrystals of zeolite $\beta$ stabilized in alumina matrix. Chem. Mater. 1999, 8, 2030-2037. [CrossRef]

29. Zhang, F.; Guo, X.; Wang, X.; Li, G.; Zhao, Q.; Bao, X.; Han, X.; Lin, L. Preparation of titanium-containing zeolites with MEL structure from B-ZSM-11 and their characterization. Appl. Catal. A 2000, 192, 157-163. [CrossRef]

30. Brodie-Linder, N.; Besse, R.; Audonnet, F.; LeCaer, S.; Deschamps, J.; Impéror-Clerc, M.; Alba-Simionesco, C. The key to control $\mathrm{Cu}$ II loading in silica based mesoporous materials. Micropor. Mesopor. Mater. 2010, 132, 518-525. [CrossRef]

31. Ma, Y.-K.; Rigolet, S.; Michelin, L.; Paillaud, J.-L.; Mintova, S.; Khoerunnisa, F.; Jean Daou, T.; Ng, E.-P. Facile and fast determination of $\mathrm{Si} / \mathrm{Al}$ ratio of zeolites using FTIR spectroscopy technique. Appl. Catal. A 2018, 559, 20-29. [CrossRef]

32. Akçay, M. The surface acidity and characterization of Fe-montmorillonite probed by in situ FT-IR spectroscopy of adsorbed pyridine. Appl. Catal. A 2005, 294, 156-160. [CrossRef]

33. Parry, E.P. An infrared Study of Pyridine Adsorbed on Acidic Solids. Characterization of Surface Acidity. J. Catal. 1963, 2, 371-379. [CrossRef]

34. Engelhardt, G.; Lohse, U.; Lippmaa, E.; Tarmak, M.; Mägi, M.Z. ${ }^{29}$ Si NMR -Untersuchungen zur Verteilung der Silicium-und Aluminiumatome im Alumosilicatgitter von Zeolithen mit Faujasit-Struktur. Anorg. Allg. Chem. 1981, 482, 49-64. [CrossRef]

35. Massiot, D.; Fayon, F.; Capron, M.; King, I.; Le Calve, S.; Alonso, B.; Durand, J.O.; Bujoli, B.; Gan, Z.; Hoatson, G. Modelling oneand two-dimensional solid-state NMR spectra. Magn. Reson. Chem. 2000, 40, 70-76. [CrossRef]

36. Hunger, M. Solid-State NMR Spectroscopy, Chapter 2. In Zeolite Characterization and Catalysis; Chester, A.W., Derouane, E.G., Eds.; Springer: Dordrecht, The Netherlands, 2009; pp. 65-105.

37. Brunner, E.; Ernst, H.; Freude, D.; Frohlich, T.; Hunger, M.; Pfeifer, H. Magic Angle Spinning NMR Studies of Acid Sites in Zeolite H-ZSM-5. J. Catal. 1991, 127, 34-41. [CrossRef]

38. van Bokhoven, J.A.; Koningsberger, D.C.; Kunkeler, P.; van Bekkum, H.; Kentgens, A.P.M. Stepwise Dealumination of Zeolite Beta at Specific T-Sites Observed with 27Al MAS and 27Al MQ MAS NMR. J. Am. Chem. Soc. 2000, 122, 12842-12847. [CrossRef]

39. Bourgeat-Lami, E.; Massiani, P.; Di Renzo, F.; Espiau, P.; Fajula, F.; Des Courières, T. Study of the state of aluminium in zeolite- $\beta$. Appl. Catal. 1991, 72, 139-152. [CrossRef]

40. Campbell, S.M.; Bibby, D.M.; Coddington, J.M.; Howe, R.F.; Meinhold, R.H. Dealumination of HZSM-5 Zeolites, I. Calcination and Hydrothermal Treatment. J. Catal. 1996, 161, 338-349. [CrossRef]

41. Yoshida, K.; Okumura, K.; Miyao, T.; Naito, S.; Ito, S.I.; Kunimori, K.; Tomishige, K. Oxidative steam reforming of methane over $\mathrm{Ni}$ /a-Al2O3 modified with trace noble metals. Appl. Catal. A 2009, 358, 186-192. [CrossRef]

42. Abu Bakar, N.H.H.; Bettahar, M.M.; Abu Bakar, M.; Monteverdi, S.; Ismail, J. Low temperature activation of Pt/Ni supported MCM-41 catalysts for hydrogenation of benzene. J. Mol. Catal. A 2010, 333, 11-19. [CrossRef] 